\title{
ROD I NACIJA: OSNOVNE PRETPOSTAVKE
}

Da li je feminizam ideologija, lično uverenje, mreža teorijskih pozicija, polazna tačka u razmatranju fenomena koji se više ne moraju ticati isključivo žena, pojmovni okvir, skup različitih aktivnosti čiji je cilj poboljšanje položaja žena, pokušaj da se istorija pročita drugačije, ili sve to zajedno? Da li postoji jedna definicija feminizma? Šta je to rod? Koja je razlika između ženskih i rodnih studija? Da li je nacija večna i univerzalna ili specifično moderna pojava? Da li žene imaju nacionalnost/otadžbinu? Zašto su predstava o naciji, konstrukcija nacionalnog identiteta kao i procesi formiranja/obrazovanja nacije prožeti rodno specifičnim konotacijama? Šta je nacionalni angažman doneo ženama? Cilj ovog teksta jeste da razjasni navedene termine i pojmove iz perspektive feminističke teorije.

Ključne reči: feminizam, pol/rod, nacija, feministički pokret, feministička teorija 


\section{ŠTA JE FEMINIZAM?}

Prema nemačkoj istoričarki Gizeli Bok (Gisela Bock), ako se pod feminizmom podrazumeva, kao što je to danas uobičajeno u zemljama engleskog govornog područja, javni ili privatni otpor protiv podređenog položaja žena, onda feminizam postoji oduvek. Ukoliko se, pak, pod feminizmom podrazumeva društveni pokret žena sa feminističkim pogledom na svet, onda je on specifična pojava 19-og, 20-og (i, dodajmo, 21-og) veka. ${ }^{1}$ Bok smatra da je do 18 . veka bilo brojnih "feminističkih glasova" ali da oni nisu mogli predstavljati pravu feminističku tradiciju, jer nije bilo predanja u okviru kog bi se kasniji ženski glasovi mogli nadovezati na one ranije. Razlog za to bio je u opštoj isključenosti žena iz obrazovanja i njegovih institucija, iz sveta znanja i biblioteka, kao i u tome da ženski glasovi nisu nalazili trajnog odjeka kod učenih muškaraca koji su imali prevlast u intelektualnoj tradiciji Evrope. ${ }^{2}$

Istoričarka Karen Ofen (Karen Offen) definiše feminizam kao sveobuhvatni kritički odgovor na svesno i sistematsko potčinjavanje žena kao grupe od strane muškaraca kao grupe u datom kulturnom kontekstu. Od sredine 19. veka istorija feminizma je na kompleksne načine bila povezana sa istorijom liberalizma, nacionalizma i socijalizma, ali i sa drugim -izmima epohe, kao i sa pojavom nacionalnih država, političkih partija, dobrotvornih i radničkih društava. ${ }^{3}$ Karen Ofen takođe smatra da se svaka osoba, bilo muškog ili ženskog pola, može nazvati feministom/kinjom ukoliko prihvata i zagovara tri načela: prepoznaje važnost ženskih interpretacija sopstvenog životnog iskustva i potreba, te pored toga priznaje vrednosti koje žene javno zastupaju kao svoje (i koje su različite od estetskog ideala ženskosti izmišljenog od strane muškaraca), vrednujući svoj status u društvu u odnosu na muškarce; pokazuje svest i nelagodu, ili čak ljutnju, povodom institucionalne nepravde spram žena kao grupe od strane muškaraca kao grupe u datom društvu; zalaže se za uklanjanje te nepravde kroz promenu vladajućih ideja odnosno društvenih institucija i praksi, to jest mehanizama pomoću kojih se održava muška prevlast $\mathrm{u}$ datom društvu. To znači da feminista/kinja mora nužno da bude $\mathrm{u}$ sukobu sa društvom i kulturom u kojima dominiraju muškarci. ${ }^{4}$

1 Gizela Bok, Žena u istoriji Evrope. Od srednjeg veka do danas, prevela Ljubinka Milenković (Beograd: Clio, 2005), 403.

2 Isto, 404.

3 Karen Offen, European Feminisms 1700-1950. A Political History (Stanford: Stanford University Press, 2000), 20.

4 Karen Offen, "Defining Feminism: A Comparative Historical Approach", Signs vol. 14, no. 1 (Jesen 1988): 152. http://www.jstor.org/stable/3174664. 
Poput nekih drugih autorki i autora, i Adriana Zaharijević široko opisuje feminizam: feminizam je, naime, kao i mnogi drugi -izmi, i pokret i ideologija, lično uverenje, mreža teorijskih pozicija, polazna tačka u razmatranju fenomena koji se više ne moraju ticati žena, pojmovni okvir, skup različitih aktivnosti čiji je cilj poboljšanje položaja u kojem se žene nalaze, a neretko i pokušaj da se istorija pročita drugačije. ${ }^{5}$ Ne postoji, dakle, jedna definicija feminizma. Pored toga, Zaharijević ističe da se feminizam ne može svesti isključivo na teoriju ili isključivo na praksu. ${ }^{6}$

Uobičajeno je da se feministički pokret deli na tri talasa. Prvi talas ili klasični ženski pokret 19. i ranog 20. veka (odnosno, prve polovine 20. veka) težio je fundamentalnoj promeni rodnih odnosa, to jest poboljšanju položaja žena u ekonomskom, društvenom, političkom i kulturnom pogledu, kako u odnosu na njihovu dotadašnju situaciju, tako i u odnosu na muškarce. Njegov cilj nije bilo izjednačavanje rodnih uloga niti zamena tih uloga već oslobađanje od biološkim polom uslovljene potčinjenosti. Klasični ženski pokret je isticao individualnost u smislu postajanja subjektom, to jest, u smislu autonomije. Tražio je dostojanstvo i slobodu za žene, često i za muškarce, nezavisno od toga da li su oni inače, čak i u metaistorijskom pogledu, "jednaki" ili "različiti”. Tačka napada nije bilo rađanje dece i materinstvo, već podređenost majki očevima. Pokret se odlučno okrenuo protiv teškog rada u kući i rasipanja snage, ali nije paušalno odbio podelu poslova na muške i ženske. Klasični ženski pokret bio je, prema Gizeli Bok, socijalni pokret, jer je žensko pitanje razumevao kao socijalno pitanje $\mathrm{i}$ jer je kao i drugi društveni pokreti toga vremena bio organizovan $\mathrm{u}$ formi "pokreta". 7

Krajem 19. veka, većina ženskih građanskih pokreta insistirala je na nezavisnosti od političkih partija, ali se uglavnom osećala bliskost s idejama liberalizma. Veza sa radničkim pokretom prekinuta je sa njegovim jačanjem - što je radnički pokret bio jači i revolucionarniji oštrije se distancirao od ženskog pokreta. Klara Cetkin (Clara Zetkin) isticala je, na primer, da ženski socijalistički pokret uopšte nije ženski pokret, to jest da se ne bori za prava "građanskih" žena, koje su smatrane za klasnog neprijatelja, već za proleterijat.

5 Adriana Zaharijević, "Kratka istorija sporova: Šta je feminizam”, u Neko je rekao feminizam. Kako je feminizam uticao na žene 21. veka, ur. Adriana Zaharijević (Beograd: Heinrich Böll Stiftung, 2012), 384.

6 Isto, 385 .

7 Bok, Žena u istoriji Evrope, 188, 200-201. 
Žensko pitanje bio je "sporedni zadatak". ${ }^{8}$ Naravno, nisu svi delili njeno mišljenje.

Drugi talas ili novi ženski pokret nastupio je krajem šezdesetih godina 20. veka: preispituju se tradicionalni koncepti ženstvenosti, koncept autoritarnog obrazovanja, otvara se pitanje abortusa, seksualnosti (homoseksualnosti), prostitucije, traži izjednačavanje plata, zahteva ukidanje rodno specifične podele rada, otvaraju "ženske kuće" za zlostavljane žene itd. Do 1975. godine prerastao je u masovni pokret, a od samog početka je podrazumevao međunarodnu komunikaciju. ${ }^{9}$ Protest Afroamerikanki u SAD protiv dominacije belkinja doveo je na međunarodnom planu do jačanja svesti o uticaju nacionalnih, etničkih i verskih razlika na položaj i potrebe žena. ${ }^{10}$

Ključno je da se do tada feminizam svodio isključivo na praksu, odnosno feminizam nije imao svoju sopstvenu teoriju. Njegova teorijska opravdanja su od 19. veka gravitirala između liberalne teorije i socijalističkih doktrina, ne iscrpljujući se ni u jednoj od njih, sumira Adriana Zaharijević. Ukazujući na uzroke podređenosti žena i načine na koje je ona opstajala vekovima, Simon de Bovoar (Simone de Beauvoir) napravila je presudni korak za feminističku teoriju. ${ }^{11}$

Ženske studije osnovane su prvo na američkim univerzitetima. ${ }^{12} \mathrm{U}$ okviru njih proučavan je, po prvi put iz feminističkog ugla, doprinos žena u društvu kojim su dominirali muškarci. U fokusu istraživanja našlo se životno iskustvo žena, kao i njihova društvena i kulturna stvarnost. Glavni zadatak bila je afirmacija ženskog iskustva kao alternativnog ali jednako vrednog društvenog fenomena. Sociološknja i profesorka rodnih i etničkih studija Nira Juval Dejvis (Nira Yuval-Davis) svela je teme kojima se bavi bogata i vrlo raznolika feministička literatura na tri glavna pitanja. Prvo pitanje jeste zašto su i kako žene potlačene? Tragalo se za strukturnim načelima koja određuju razlike u moći između muškaraca i žena. Teorije o patrijarhatu (pod pojmom "patrijarhat" feminističke teoretičarke podrazumevaju autonomni sistem podređivanja žena u društvu) nalaze se od početka u središtu feminističke teorije. Analize se bave prevashodno tumačenjima društvenih sfera, poput dihotomije javno/privatno ili priroda/civilizacija. Drugo pitanje odnosi se na ontološki temelj razlika između

\footnotetext{
8 Isto, 192.

9 Isto, 369-373.

10 Isto, 376.

11 Zaharijević, "Kratka istorija sporova: Šta je feminizam”, 398-399.

12 U Evropi je istorija žena otkrivena sredinom sedamdesetih godina 20. veka. Bok, Žena u istoriji Evrope, 401.
} 
muškaraca i žena: da li su te razlike određene biološki, društveno ili kombinacijom jednog i drugog. Treće pitanje, u velikoj meri reakcija na neke preterano etnocentrične i zapadnocentrične zaključke rane feminističke teorije, odnosi se na razlike među ženama i među muškarcima, kao i na to kako te razlike utiču na uopštena poimanja rodnih odnosa. Ovom problematikom najpre su se bavile samo crnkinje i pripadnice etničkih manjina. ${ }^{13}$

Tokom sedamdestih i osamdesetih godina 20. veka feminističke politike su se delile na oštro odvojene pravce liberalnog, socijalističkog, radikalnog i "mešovitog" feminizima. ${ }^{14}$ Razlika među tim pravcima ogledala se prevashodno u odgovoru na pitanje šta je pravi uzrok potčinjenosti žena - da li je to zakon, kapitalizam ili jednostavno muškarci koji se ne žele odreći svojih privilegija. Silvija Volbi (Sylvia Walby) razlikuje oblike patrijarhata u različitim društvenim područjima - zapošljavanju, kućnoj radinosti, kulturi, seksualnosti, nasilju i državi. U radovima britansko-američke politikološkinje Kerol Pejtman (Carole Pateman) patrijarhat je obeležje predmodernog istorijskog perioda. U modernoj liberalnoj državi, prema njenom mišljenju, patrijarhalni sistem se pretvara u bratstvo. Dok je u patrijarhatu otac imao vlast i nad ženama i muškarcima, u bratstvu muškarci među sobom sklapaju društveni ugovor o jednakosti u društvenoj javnoj sferi, a imaju pravo vladati svojim ženama u privatnoj sferi. Druge autorke su patrijarhat ograničile na određene društvene institucije, istorijska razdoblja ili geografska područja. S druge strane, Floja Antis (Floya Antis) i Nira Juval Dejvis odbacile su pojam patrijarhata kao posebnog društvenog sistema koji je nezavistan od drugih tipova društvenih sistema, poput kapitalizma i rasizma. One smatraju da kada se u obzir uzme raspodela moći i materijalnih resursa u društvu potčinjavanje žena predstavlja poseban i nedeljiv deo društvenih odnosa. Žene uglavnom nisu samo objekti i nečinioci u procesu definisanja rodnih odnosa. Čak i unutar istog društva u datom momentu nisu sve žene podjarmljene na isti način ili u istoj meri. ${ }^{15}$

13 Nira Yuval-Davis, Rod i nacija, prevela Mirjana Paić Jurinić (Zagreb: Ženska infoteka, 2004), 15-16.

14 Opširnije: Sylvia Walby, Theorizing Patriarchy (Cambridge: Basil Blackwell, 1990), 3-7. Vidi takođe: Adriana Zaharijević, "Dodatak 7: Feminističke teorije, pozicije i teorijski okviri”, u Neko je rekao feminizam. Kako je feminizam uticao na žene 21. veka, ur. Adriana Zaharijević (Beograd: Heinrich Böll Stiftung, 2012), 416-424.

15 Yuval-Davis, Rod i nacija, 17-19. 


\section{ROD}

Osamdesetih godina 20. veka pomeranje fokusa istraživača na rod, ženski kao i muški, na razlike između pola i roda, odnosno rodne odnose, dovodi do razvoja rodnih studija. Ova disciplina bavi se vezom između roda i kulture/društva/nauke, te postavlja pitanje kako rod utiče na ljudske zajednice $i$, obrnuto, kako one utiču na formiranje roda. Istorijski gledano, postoji uska povezanost između novog ženskog pokreta i ženskih odnosno rodnih studija. ${ }^{16}$ Regina Beker Šmit (Regina Becker-Schmidt) smatra da studije roda ne predstavljaju alternativu ženskim studijama, već da oba pristupa imaju svoje opravdanje i smisao.

Razlikovanje termina pol i rod potiče iz medicinsko-psihijatrijskih diskusija vođenih tokom pedesetih godina 20 . veka na temu transseksualnosti. ${ }^{17}$ Sedamdesetih i osamdesetih godina feminističke teoretičarke okrenule su se rodu kao pojmu zgodnom za ponovno promišljanje odnosa između polova. One su smatrale da je od velike važnosti da razdvoje biologiju od kulture te da opravdaju tu promenu kao jedan vid istorije a ne radikalnih društvenih previranja. $U$ to doba je termin rod obavljao važan teorijski posao. Sama reč - gramatički pojam prebačen u društvenu/kulturnu arenu - bila je uznemirujuća. Feministkinje su pod okriljem roda proučavale kako su i u kojim uslovima različite uloge i funkcije definisane za svaki pol, kako su sama značenja kategorija "muškarac" i "žena” varirala u skladu sa istorijskom epohom i geografskim mestom, kako su formirane i sprovođene regulatorne norme polnog ponašanja, kako su se teme moći i prava uklapale u pitanja muškosti i ženskosti, kako su simbolička ustrojstva uticala na život i rad običnih ljudi, te kako su se oblikovali polni identiteti unutar i izvan propisanih društvenih pravila. ${ }^{18}$

Prema shvatanju čuvene istoričarke Džoan Skot (Joan WallachScott), u najnovijoj upotrebi rod se najpre pojavio među američkim feministkinjama koje su zastupale primarno društvenu kvalitetu različitosti utemeljenih na polu. Reč rod označavala je odbacivanje biološkog determinizma sadržanog u upotrebi termina kao što su pol i polna različitost. Rod je isticao relacioni/odnosni aspekt normativnih definicija ženskosti. Prema tom stajalištu, žene i muškarci su definisani međusobno, jedni na temelju drugih, što znači da se potpuno

16 Regina Becker-Schmidt i Gudrun-Axeli Knapp, Feministische Theorien zur Einführung (Hamburg: Junius, 2000), 7.

17 Isto, 69 .

18 Joan Wallach-Scott, Rod i politika povijesti, prevela Marina Leustek (Zagreb: Ženska infoteka, 2003), 11-12. 
odvojenim proučavanjem nije moglo doći do razumevanja ni jednih ni drugih. ${ }^{19}$

Sama Džoan Skot vidi rod kao korisnu analitičku kategoriju. Ona je definisala rod kao konstitutivni element društvenih odnosa koji počiva na svesti o razlikama između polova. Rod se konstruiše kroz četiri elementa: simbole, normativne koncepte, društvene institucije i procese, te subjektivni identitet. U drugom delu definicije Skot je označila rod kao primarni način označavanja odnosa moći. Promene u organizaciji društvenih odnosa odgovaraju promenama u oblicima predstavljanja moći, ali se promena ne zbiva nužno u samo jednom smeru. ${ }^{20}$ Rodna hijerarhija, koja se percipira kao prirodna, često se koristi prilikom legitimizacije ostalih oblika hijerarhije i moći. Rod je jedna od povratnih uputnica pomoću kojih se politička moć smišlja, odobrava i kritikuje. On upućuje na značenje muško/ženske opozicije, no isto tako ga i uspostavlja. Da bi opravdala i odbranila političku moć, ta se uputnica mora doimati sigurnom i fiksnom, izvan dosega ljudske interpretacije, kao deo božanskog ili prirodnog poretka. Na taj način i binarna opozicija i društveni proces rodnih odnosa postaju delom samog značenja moći; ispitivati ili menjati bilo koji od aspekata ugrožava celokupan sistem..$^{21}$

Džoan Skot, dakle, smatra da nisu genetske, hormonalne ili anatomske razlike odgovorne za formiranje rodnih uloga i samopercepcije, odnosno hijerahije i mehanizama za isključivanje, već zaključci koji su na osnovu tih razlika izvedeni. Ukoliko su razlike između muškaraca i žena društveno konstruisane i proizvedene - ukoliko nisu urođene - onda se one mogu i menjati. ${ }^{22}$

Pojedine feminističke teoretičarke smatrale su da je podela na pol/ rod problematična. Gizela Bok je odbacila ideju biologije kao prirodne i nepromenjive komponente i predložila da se rod proučava kao celokupna kategorija koja uključuje polne i kulturno konstruisane komponente. ${ }^{23}$ Džudit Batler (Judith Butler), američka filozofkinja i filološkinja, odbacila je u potpunosti distinkciju pol/rod (početkom

\footnotetext{
19 Isto, 48.

20 Isto, 64-65.

21 Isto, 71.

22 Po mišljenju Džoan Skot, krajem devedesetih godina rod je izgubio sposobnost da "zaprepasti i izazove". Termin je postao sinonim za označavanje kategorije žene. Skot se sve manje služila tim pojmom i radije govorila o razlikama između polova i polu kao istorijski varijabilnom konceptu. Isto, 12.

23 Gisela Bock, "Geschichte, Frauengeschichte, Geschlechtergeschichte”, Geschichte und Gesellschaft vol.14, no. 3 (1988): 374-378.
} 
1990-ih godina), proglasivši pogrešnom pretpostavku da se rod bazira na polu kao ontološkom i nepromenjivom fenomenu. Batler smatra da je i pol kulturološki konstruisan pojam te stoga prestaje biti temelj, već postaje element u konstrukciji roda. ${ }^{24}$ Dekonstrukcija pojmova pol i rod, a samim tim i kategorije žena, vodila je sledećim pitanjima: šta - ukoliko bilo šta - povezuje žene, šta znači biti žena i kakve zahteve mogu feministkinje da postavljaju u ime žena. ${ }^{25}$

Juval Dejvis u svojoj knjizi Rod i nacija piše da bi rod trebalo razumeti ne kao neku "stvarnu" društvenu razliku između muškaraca i žena, nego kao oblik diskursa koji se odnosi na skupine subjekata čije društvene uloge određuje njihova polna/biološka razlika, za razliku od njihovog ekonomskog položaja ili pripadnosti etničkim i rasnim kolektivima. Polne razlike bi takođe trebalo razumeti kao oblik diskursa u kome se za skupine društvenih subjekata drži da su različito polno/biološki konstituisane. To jest, i pol i rod mogu se analizirati kao oblici diskursa, ali s drugačijim motivima. ${ }^{26}$

Nasuprot ideji o diskurzivnoj prirodi pola/roda, koncept "činjenja roda" (doing gender) ističe da rodne razlike i identiteti mogu da budu realizovani tek u socijalnoj interakciji, to jest u svakodnevnom životu. ${ }^{27}$ Shodno tome, rod nije nešto što imamo ili jesmo, već ono što činimo. Prema ovom konceptu, individue nisu zamišljene kao "zatvorenici” diskurzivnih ili nekih drugih struktura. One se promatraju kao akteri, koji u svakoj situaciji imaju na raspolaganju više ili manje širok repertoar načina ponašanja i značenja, iz kog oni odabiru kako će delovati. ${ }^{28}$

Tokom devedestih godina dolazi do sveobuhvatne razgradnje feminizma. Čini se da se u tom trenutku teoretičarke i aktivistkinje nalaze na suprotnim polovima, kao i da feministička teorija ostaje bez svog dugo traženog i teško uspostavljenog subjekta. Paradoksal-

24 Džudit Batler, Nevolja s rodom. Feminizam i subverzija identiteta, prevela Adriana Zaharijević (Loznica: Karpos, 2016), 48-50.

25 Ana Z. Kolarić, "Rod, književnost i modernost u periodici s početka 20. veka: Žena i The Freewoman (1911-1912)”. Doktorska disertacija. Univerzitet u Beogradu, 2015, 25. Ana Kolarić, Rod, modernost i emancipacija:Uredničke politike u časopisima "Žena" (1911-1914) i "Freewoman" (1911-1912) (Beograd: Fabrika knjiga, 2017).

26 Yuval-Davis, Rod i nacija, 20-21.

27 Kao i diskurs-analitički koncept, etnometodološki polazi od toga da rodni identiteti nisu urođeni, bezvremeni i nepromenjivi, kao i da ljudi ne ispoljavaju svoj rodni identitet na isti način.

28 Claudia Opitz-Belakhal, Geschlechtergeschichte (Frankfurt-New York: Campus Verlag, 2010), 27-28. 
no, vrlo složenim i većini žena nerazumljivim jezikom teoretičarke pokušavaju da vrate feminizam svim onim ženama koje su iz njega bile de facto isključene. Alternativa politici identiteta, ideja "politike razlika", formulisana je na univerzitetima, uz rađanje novih teorijskih disciplina kakve su "queer" i postkolonijalna teorija, crnačke studije ili studije etniciteta. Feministkinje trećeg talasa zalažu se za to da neke nove koalicije ubuduće treba zasnivati na inkluzivnom "afinitetu” ${ }^{29}$ umesto na isključujućem identitetu. ${ }^{30}$

\section{NACIJA}

U ranoj fazi ženskih studija vladalo je mišljenje da su nacionalne ideologije i nacija bile isključivo muškog pola, to jest, da žene nemaju nacionalnost/otadžbinu. U međuvremenu, brojna istraživanja dokazala su da postoji kompleksna veza između ženskog političkog angažmana i nacionalnog identiteta, te da su predstava o naciji, kao i konstrukcija nacionalnog identiteta i procesi formiranja/obrazovanja nacije prožeti rodno specifičnim konotacijama. Svaki nacionalni projekat u svojoj reprezentaciji, kao i u političkoj praksi, u socijalizaciji kao i u politici identiteta, sadrži rodno specfične karakteristike. Ženama i muškarcima su dodeljene različite sfere i identiteti koji se međusobno dopunjavaju. ${ }^{31}$

Latinska reč natio ušla je relativno kasno u evropske jezike, i to ne sve jezike. U 18. veku upotrebljavane su dve varijante ove reči koje su imale potpuno različita značenja. U skladu sa osnovnim latinskim značenjem, od antike i srednjeg veka pod terminom natio podrazumevala se zajednica koja ima zajedničko poreklo. Kao kriterijum pripadnosti zajednici važio je pre svega jezik, pa zajednička istorija, koja od kasnog srednjeg veka postaje predmetom istraživanja. U tom smislu, nacije su postale subjekti sopstvene nacionalne istorije. Pri-

29 Zaharijević se ovde poziva na Donu Haravej (Donna Haraway) i njen "Manifest za kiborge”, u kom Haravej kritikuje različite feminističke struje i zamišlja društvo bez roda, posvećeno izgradnji takve političke forme koja će uspeti da udruži različite ljude oko jedne ideje, političkog programa, do njene/njegove realizacije. Zaharijević, "Kratka istorija sporova: Šta je feminizam", 415. Vidi i Dona Haravej, "Manifest kiborga", prevela Branka Arsić. http://www.womenngo.org.rs/sajt/ sajt/izdanja/zenske_studije/zs_s2/kibor.html.

30 Zaharijević, “Kratka istorija sporova: Šta je feminizam”, 414.

31 Ute Planert, "Vater Staat und Mutter Germania: Zur Politisierung des weiblichen Geschlechts im 19. und 20. Jahrhundert", u Nation, Politik und Geschlecht. Frauenbewegungen und Nationalismus in der Moderne, ur. Ute Planert (FrankfurtNew York: Campus Verlag, 2000), 19. 
pisivan im je određen, zaseban karakter i obeležja. Termini nacija i narod se nisu mnogo razlikovali po svom značenju.

U Didroovoj enciklopediji pod terminom nacija podrazumevalo se stanovništvo jedne države, sa zajedničkom vladom i zakonima. Budući da su u doba apsolutizma različiti zakoni važili za različite socijalne grupe, termin nacija se odnosio samo na one koji su posedovali politička prava (aristokratiju, eventualno aktivne građane). U nekim evropskim zemljama termin narod koristio se za označavanje onih slojeva stanovništva koji nisu imali politička prava. Sa Rusoovim konceptom društva, u kojem je nacija sastavljena od (svih) ravnopravnih (muških) građana bila vrhovni suveren, termin nacija bio je radikalno preformulisan. Termini nacija i narod postali su sinonimi. Ovaj model o demokratskoj naciji temeljio se na dva principa, koji su do današnjeg dana konstitutivni principi svakog demokratskog društva: principu narodnog suvereniteta i neotuđivih ljudskih prava. ${ }^{32}$

Benedikt Anderson (Benedict Anderson) naciju definiše kao zamiŠljenu političku zajednicu, i to zamišljenu kao ograničenu i suverenu. Nacija je "zamišljena" zato što pripadnici čak i najmanje nacije nikad neće upoznati većinu drugih pripadnika svoje nacije, no u mislima svakog od njih živi slika njihovog zajedništva. Nacija se zamišlja kao "ograničena" jer svaka nacija, pa i ona najveća, ima svoje određene, iako varijabilne granice. Bez razgraničenja u odnosu na druge nema ni nacije. Nacija se pored toga zamišlja kao "suverena" jer se pojam pojavio u trenutku u kom su prosvetiteljstvo i revolucija razorili legitimitet dinastičkih carstava stvaranih po milosti božijoj. Na mesto božanske milosti stupio je ideal slobode, a suverena država postala je simbol tog ideala. Na kraju, nacija se zamišlja kao "zajednica" zato što se bez obzira na stvarnu nejednakost i izrabljivanje koji mogu u njoj vladati, ona poima kao drugarski savez jednakih. Upravo je to fiktivno, u najvećoj meri apstraktno i nerealno bratstvo bilo razlog zbog kog su u poslednjih dve stotine godina milioni ljudi bili spremni ne samo da ubijaju za naciju, nego i da umiru za nju. ${ }^{33}$

Prema Ernestu Gelneru (Ernest Gellner), kao i Andersonu, nacije nisu neka večna i univerzalna nego specifično moderna pojava, koja se razvija na prelazu iz agrarnog u industrijsko društvo. Nacija nije, dakle, "prirodna" konstanta koja se "ponovo budi", već konstrukcija

32 Otto Dann, "Begriffe und Typen des Nationalen in der frühen Neuzeit", u Nationale und kulturelle Identität. Studien zur Entwicklung des kollektiven Bewusstseins in der Neuzeit, ur. Bernhard Giesen (Frankfurt a. M: Suhrkamp, 1991), 58-59.

33 Benedikt Anderson, Nacija: zamišljena zajednica, prevele Nata Čengić i Nataša Pavlović (Beograd: Plato, 1998), 17-18. 
koja izlazi u susret potrebama industrijalizacije. Učenik Ernesta Gelnera britanski sociolog Entoni D. Smit (Anthony D. Smith), u čijem se fokusu istraživanja nalaze nacionalizmi i etnički kolektivi, slaže se sa takozvanim modernistima da je nacionalizam kao pokret i ideologija posve moderna pojava, ali tvrdi da u praksi moderna nacija sadrži nekoliko obeležja predmoderne etnije. Primordijalisti, dakle, smatraju da je nacija prirodna i univerzalna veličina. Za moderniste Hobsboma (Eric Hobsbawm), Andersona i Gelnera, nacija je konstrukt i fenomen vezan za modernu. ${ }^{34}$ Smit, po nekima pomiritelj primordijalizma i modernizma, razvio je istorijski etnosimbolizam. Po njegovom mišljenju, nacija i nacionalizam nisu isključivo ideološke tvorevine ili oblik politike, već i kulturne pojave. Shodno tome, ukoliko neka nacija želi da opstane u današnjem svetu ona se mora izboriti za taj svoj opstanak i na političkoj i na kulturno-identitetskoj ravni. Nacija i nacionalizam su po Smitu "stvarne i moćne sociološke pojave" u čijoj snazi mitovi (naročito mit o izabranosti), kao deo kulture, igraju veliku ulogu. ${ }^{35}$

\section{FORMIRANJE NACIJE I EMANCIPACIJA ŽENA KRAJEM 19. I POČETKOM 20. VEKA NA PROSTORU NA KOM SU ŽIVELI SRBI}

U ovom delu osvrnućemo se na formiranje srpske nacionalne države i srpske nacije, kao i na ulogu koju su u tim procesima imale žene. Štaviše, opisaćemo kako su nacionalna ideja i ideja o ženskoj emancipaciji išle ruku pod ruku.

Nemački istoričar Holm Zundhausen (Holm Sundhaussen) smatra da, za razliku od nacije, etnos (etnička zajednica) ne teži stvaranju vlastite države i odlikuje ga niži stepen društvene i političke organizacije. ${ }^{36}$ Ovde valja spomenuti i češkog istoričara Miroslava Hroha (Miroslav Hroch), koji je razradio model u tri faze za "buđenje" "malih", u polaznoj situaciji politički i socijalno obespravljenih, naroda. Unutar procesa obrazovanja nacije Hroh razlikuje fazu (A) naučničkog patriotizma jedne brojno slabe u biti nepolitičke grupe intelektualaca, fazu (B)

34 Yuval-Davis, Rod i nacija, 28-29.

35 Opšrirnije vidi: Srđan Šljukić, "Entoni Smit o odnosu nacionalnog identiteta i mita o izabranosti”, Zbornik Matice srpske za društvene nauke no. 139 (februar 2012), 284-285, 288. http://www.maticasrpska.org.rs/stariSajt/casopisi/drustvene_nauke_139.pdf.

36 Holm Sundhaussen, "Nationsbildung und Nationalismus im Donau-Balkan-Raum”, Forschungen zur osteuropäische Geschichte no. 48 (1993): 236. 
svesno usmerene političke agitacije jedne nacionalno svesne manjine i fazu (C) integralnog masovnog nacionalizma. ${ }^{37}$ Zundhausen je ovaj Hrohov model adaptirao i primenio na primeru Srbije.

Zundhausen smešta početak faze A na prag 19. veka. Karakterističan za ovu fazu jeste novi odnos prema narodnom jeziku i narodnoj kulturi, u skladu sa idejama raširenim na prelazu iz prosvetiteljstva u romantizam u srednjoj Evropi. Ove ideje širila je jedna grupa učenih ljudi koji su predano izučavali jezik, kulturu i istoriju svog naroda, pisali gramatike i rečnike, sakupljali narodne pesme i pisali istorijske rasprave. Najznačajniji predstavnici jesu Dositej Obradović i Vuk Stefanović Karadžić. Zunhausen se ograđuje i kaže da to ne znači da nije bilo preteča, i to pre svega među habsburškim Srbima. Faza B započinje, po njegovom mišljenju, sa formulisanjem nacionalno-političkog programa Ilije Garašanina. Zundhausen ističe da je Srbija, za razliku od naroda koje je Hroh proučavao, tada već imala svoju državu, ali ona nije obuhvatala sve teritorije koje su prema ovoj mentalnoj mapi smatrane za srpske. Otvaranjem velike istočne krize 1875. godine počinje faza $\mathrm{C}$, koja traje sve do kraja balkanskih odnosno Prvog svetskog rata. U fazi masovne mobilizacije stanovništva preduslovi su medijalizacija, inscenacija nacije uz pomoć simbola, praznika, spomenika, muzeja i slično, inkorporiranje nacionalnog u svakodnevni život, percepcija stanovništva kao zajednice jednakih, odnosno kao bratstva. Rat je u ovoj vizuri posmatran kao sredstvo, koje se pokazalo vrlo efikasno, za postizanje homogenosti i stvaranje nacionalne svesti, osećaja zajedništva. Po Zundhausenu, proces obrazovanja srpske nacije je završen do kraja Prvog svetskog rata. ${ }^{38}$

\section{DA LI JE PRIRODNA ULOGA MUŠKARACA VOJEVANJE? DA LI JE CARSTVO ŽENA KUĆA, A CARSTVO MUŠKARACA DRUŠTVO?}

Među pripadnicima Ujedinjene omladine srpske raspravljalo se, pored toga da li žene mogu da budu ravnopravni članovi ovog patriotskog udruženja, o tome kako žene mogu da doprinesu ostvarenju nacionalnog ujedinjenja. Članica "Omladine" i borkinja za oslobođenje žena od očinske (roditeljske) i muževljeve vlasti, Draga Dejanović, stavljala je znak jednakosti između oslobođenja naroda i oslobođenja žena. Prema

37 Prema Holm Zundhausen, Istorija Srbije od 19. do 21. veka, preveo Tomislav Bekić (Beograd: Clio, 2009), 94.

38 Isto, $146-150$. 
njenom mišljenju, zadatak žene bio je da vaspitava buduće generacije u nacionalnom duhu, čuva narodnu tradiciju i običaje i rađa. To znači da je majčinstvo, po njenom mišljenju, spadalo u sferu javnog/političkog, a ne privatnog. Dejanović se zalagala za emancipaciju žene u ravnopravnog člana nacije, kao i za to da vernost naciji, a ne pol bude preduslov učešća u javnom životu. U nacionalne dužnosti žena ubrajala se nega ranjenika u ratu (da pruže logističku podršku vojsci), društveno-dobrotvorni rad u miru (osnivanje vrtića, škola, bolnica, staračkih domova, domova za ratne invalide, sakupljanje finansijske pomoći za ugrožene od prirodnih i drugih katastrofa, siromašne i slično), ali i vršenje nacionalne propagande i očuvanje sećanje na poginule u ime nacije.

U isto vreme, tokom 19. veka, uvođenjem opšte vojne obaveze i stvaranjem narodnih armija, vojska se prezentuje kao "škola” muškog dela nacije. Spremnost i sposobnost da se brani nacija i otadžbina postaju glavne muške vrline ${ }^{39}$ Rodni identitet muškaraca biva nacionalizovan i militarizovan: "Priroda i sada, kao i pre, neguje Srbina za vojnika i borca." ${ }^{40}$ Pravo nošenja oružja i ubijanja bilo je u principu rezervisano za muškarce. Žene-borci su tokom ratova vođenih u periodu između 1876. i 1918. godine bile tolerisane u redovima srpske vojske, ali država nikada nije pokušala da masovno mobiliše žene. Na rat se gledalo kao na muški posao. Primetno je da su ženska društva slavila herojske podvige svojih članica (prilikom osnivanja bolnica, nege ratnika, sakupljanja novca za sanitetski materijal i slično) tokom ratova, ali se nisu konkretno pozivala na podvige ratnica. ${ }^{41}$

Početak samostalnog organizovanja žena u Srbiji pada u sredinu sedamdesetih godina 19. veka, u vreme Bosansko-hercegovačkog ustanka. Osnivanjem svojih (patriotskih i dobrotvornih) društava žene su postale vidljive u javnoj sferi i dobile priliku da, nezavisno od političkih organa, državnih i drugih institucija u koje su pristup imali samo muškarci, organizovano sudeluju u nacionalnim i društvenim zbivanjima. U okviru udruženja njegove članice su sakupljale nova iskustva, sticale političke veštine i usavršavale se u komunikaciji sa javnim instancama. Organizovanim istupanjem u javnoj sferi signalizovale su da su zainteresovane za događaje izvan svoje kuće, da su sposobne za preuzimanje društvene odgovornosti, te da se znaju samostalno, demokratski organizovati. S druge strane, formiranje

39 Svetlana Stefanović, "Nation und Geschlecht. Frauen in Serbien von der Mitte des 19. Jahrhunderts bis zum Zweiten Weltkrieg" (PhD diss., Univerzitet u Lajpzigu, 2013), 241-254. http://nbn-resolving.de/urn:nbn:de:bsz:15-qucosa-203559.

40 Jovan Dragašević, “Svakidašnja misao”, Vojin III (1866): 98.

41 Opširnije vidi: Stefanović, "Nation und Geschlecht”, 254-261. 
ženskih društava doprinelo je obrazovanju novog ženskog identiteta, to jest razvijanju političkih i emancipatorskih aspiracija. ${ }^{42}$

Samostalno (kao pojedinci) ili organizovano (kroz udruženja) žene su delovale u javnoj sferi. One možda nisu donosile političke odluke, odlučivale o ratu i miru, ali se ne može poreći da su bile akteri u istorijskim zbivanjima. Iako su članice ženskih udruženja u ratovima učestovale pre svega iz osećaja patriotske dužnosti, treba naglasiti da su političke i emancipatorske aspiracije takođe stajale u pozadini njihovog angažmana. Srpski narodni ženski savez, koji su 1906. godine osnovala patriotska i dobrotvorna ženska udruženja, u svom programu je istakao da se bori i za pravo glasa žena. Protivnicima ravnopravnosti oba pola, koji su postojeće stanje branili argumentom da žene ne služe vojsku, poručivalo se da je ekvivalent služenju vojske "rađanje sinova", budućih vojnika, branitelja otadžbine.

Po završetku Prvog svetskog rata i nakon raspršenih nada da će Vidovdanskim ustavom ženama biti zagarantovano pravo glasa, $\mathrm{u}$ Kraljevini Srba, Hrvata i Slovenaca (SHS) formirao se pokret za žensko pravo glasa. Zahtev za aktivno i direktno učešće žena u političkom životu zemlje nije naišao na široko odobravanje u vladajućim krugovima tog doba. U prvoj fazi borbe za pravo glasa, koja je trajala do donošenja Ustava, ženski pokret se pozivao na herojsku ulogu žena tokom nacionalne borbe i ratova između 1912-1918. Srpkinje su proglašene vestalinkama nacionalne svesti koje su za vreme neprijateljske okupacije Srbije tokom Prvog svetskog rata stvorile "front za nacionalni otpor i fizički opstanak". ${ }^{43}$ Neke aktivistkinje smatrale su da je srpska žena svoj istorijski zadatak izvršila tako što je za vreme vladavine Osmanlija sačuvala "srpsku rasu u svoj svojoj čistoti”. ${ }^{44}$ Pored pripadnica ženskog građanskog pokreta, i socijalistkinje su svoj zahtev za političkim pravima temeljile na ulozi žena u ratovima. ${ }^{45}$ Posle usvajanja Vidovdanskog ustava, koji ženama nije zagarantovao pravo glasa, pokret za ženska politička prava se reorganizovao. Jedan deo aktivistkinja zastupa stav da nije u interesu nacije i države da se poteže ovo pitanje, dok drugi, manji deo osniva Feminističku alijansu čiji je primarni cilj širenje akcije za dobijanje prava glasa, te ostvarivanje potpune ravnopravnosti žena sa muškarcima u javnom i privatnom životu. Tada su prvi put politički, ekonomski i društveni

42 Svetlana Stefanović, “Žene u službi nacije i vojske”, Knjiženstvo br. 6 (2016). http://www.knjizenstvo.rs/magazine.php?text=197.

43 Mileva Petrović, “Opštinski izbori i naše žene”, Ženski pokret br. 2 (1920): 10. 44 Delfa Ivanić, "Naše žene u svojoj društvenoj ulozi”, Ženski pokret br. 4 i 5 (1920): 23. 45 Stefanović, "Žene u službi nacije i vojske”. 
položaj žena dobili priroritet nad nacionalnim. Građanski i radnički ženski pokret - nezavisno jedan od drugoga, a povremeno sarađujući jedan sa drugim - vodili su borbu za politička prava žena. ${ }^{46}$

Poput istoričarke Ane Stolić, smatramo da ne treba prenebregnuti "različite vidove emancipatorskog delovanja u društvima Jugoistočne i Istočne Evrope", koji se javljaju u krilu nacionalnih pokreta, to jest država ${ }^{47}$ Brojni istoriografski radovi na temu nacija i rod pokazali su da su se žene od početka 19. veka pozivale upravo na naciju i otadžbinu da bi opravdale svoj politički angažman. Rad na nacionalnom polju omogućio im je da istupe iz privatnog domena i prošire svoj delokrug. Još je Olimpija de Guž (Olympe de Gouges) pisala da "la nation" nije muška, već da ujedinjuje muškarce i žene. Nasuprot onima koji su tvrdili da je politička aktivnost dužnost muškaraca, mnoge žene su sebe označavale stubovima nacije, a naciju posmatrale kao jednu veliku porodicu u kojoj muškarci i žene sarađuju. ${ }^{48}$

\section{ZAKLJUČAK}

Položaj žena razlikovao se od zemlje do zemlje, pa tako ženski pokret nikako nije bio homogen. ${ }^{49}$ Kao i kod drugih pokreta, vladalo je nejedinstvo oko prioriteta i programa, savezništava i protivništava, prijateljstava i neprijateljstava, stila i strategije, kolidirajućih ili komplementarnih lojalnosti grupama u koje su bile uključene i žene a dominirali muškarci..$^{50} \mathrm{Zbog}$ toga što žene ne čine posebnu društvenu grupu, već su bile (i jesu i dalje) prisutne u svim društvenim grupama, ženski pokreti su trošili značajan deo svoje energije na prevazilaženje različitih lojalnosti i razmimoilaženja. ${ }^{51}$

Nacionalizam žena oscilirao je, kao i nacionalizam uopšte, između participatorskih aspekata (nacionalna lojalnost i i građanstvo činili su se nedeljivim), s jedne strane, i onih isključivih ili čak agresivnih, s druge. U nekim zemljama žene su biračko pravo dobile na osnovu svog nacionalnog angažmana (Finkinje u sklopu nacionalnog oslobođenja od ruske vlasti; Norvežanke su podržale odvajanje od Švedske; Irkinje su zagovarale nacionalnu nezavisnost od Velike Britanije). Za

46 Stefanović, "Nation und Geschlecht", 335-353.

47 Ana Stolić, Sestre Srpkinje. Pojava pokreta za emancipaciju žena i feminizma u

Kraljevini Srbiji (Beograd: Evoluta, 2015), 8.

48 Bok, Žena u istorïi Evrope, 214, 229.

49 Ova konstatacija primenjiva je i na feministički pokret danas.

50 Bok, Žena u istorïi Evrope, 191-192.

51 Isto, 193. 
vreme Prvog svetskog rata nacionalizam je i u ženskim pokretima zaraćenih strana dosegao vrhunac. ${ }^{2}$

Ženski pokret koji se formirao u Kraljevini SHS (Jugoslaviji) bio je autohton, ali je bio i deo međunarodnog ženskog pokreta (za pravo glasa), što znači da feminizam na ovim prostorima ima tradiciju. Upravo u međuratnom periodu feministkinje stavljaju specifične interese žena ispred nacionalnih, zbog čega su bile optužene za rušenje "moralnih temelja porodice, građanskog društva i države", a naročito za "bolesno" primanje "štetnih zapadnih kulturnih uticaja". ${ }^{33}$ Građanski ženski pokret verovao je da se jednakost žena i muškaraca može postići pravnim sredstvima i postepenom socijalnom reformom. Mada je zastupao političku neutralnost, pripadnice Komunustičke partije Jugoslavije imale su upliv na uređivačku politiku časopisa Ženski pokret 1920-ih godina. Unutar njegovih redova delovala je od polovine 1930-ih godina Omladinska sekcija (simpatizerke KPJ).

Uprkos brojnim nacionalnim ideološkim i političkim suprotnostima u prvoj Jugoslaviji, pripadnice ženskih pokreta su dobro sarađivale. Unutar klasičnog jugoslovenskog ženskog pokreta pacifističke ideje igrale su takođe važnu ulogu (Mala ženska antanta, Ženska liga za mir $i$ slobodu osnovane su 1923. odnosno 1928. godine). ${ }^{54}$ Premda se feministički pokret u Srbiji tokom 1990-ih i 2000-ih ne naslanja izravno na tradiciju klasičnog jugoslovenskog ženskog pokreta, u cilju lakšeg razumevanja istorije ženskog odnosno feminističkog pokreta dat je kratak prikaz ciljeva i delovanja prvog talasa.

\section{LITERATURA}

Anderson, Benedikt. Nacija: zamišljena zajednica. Prevele Nata Čengić i Nataša Pavlović. Beograd: Plato, 1998.

Batler, Džudit. Nevolja s rodom. Feminizam i subverzija identiteta. Prevela Adriana Zaharijević. Loznica: Karpos, 2016.

Bock, Gisela. "Geschichte, Frauengeschichte, Geschlechtergeschichte”. Geschichte und Gesellschaft vol. 14, no. 3 (1988): 364-391.

52 Isto, 229-230.

53 Miloš Parenta, “Ženin društveni položaj”, Glasnik Srpske pravoslavne patrijaršije br. 18 (1927): 276-278.

54 Jugoslovenske feministkinje smatrale su da je mirovna koegzistencija među državama moguća, kao i da rat ne odgovara normalnom stanju čovečanstva. Opširnije Stefanović, "Nation und Geschlecht", 368-370. 
Bok, Gizela. Žena u istorïi Evrope. Od srednjeg veka do danas. Prevela Ljubinka Milenković. Beograd: Clio, 2005.

Becker-Schmidt, Regina i Gudrun-Axeli Knapp. Feministische Theorien zur Einführung. Hamburg: Junius, 2000.

Dann, Otto. "Begriffe und Typen des Nationalen in der frühen Neuzeit”. U Nationale und kulturelle Identität. Studien zur Entwicklung des kollektiven Bewusstseins in der Neuzeit. Ur. Bernhard Giesen. Frankfurt a. M: Suhrkamp, 1991, 56-73.

Dragašević, Jovan. “Svakidašnja misao”. Vojin III (1866).

Haravej, Dona. "Manifest kiborga", prevela Branka Arsić. http:// www.womenngo.org.rs/sajt/sajt/izdanja/zenske_studije/zs_s2/kibor.html.

Kolarić, Ana Z. Rod, književnost i modernost u periodici s početka 20. veka: Žena i The Freewoman (1911-1912). Doktorska disertacija. Univerzitet u Beogradu, 2015.

Kolarić, Ana. Rod, modernost $i$ emancipacija:Uredničke politike u časopisima "Žena" (1911-1914) $i$ "Freewoman" (1911-1912). Beograd: Fabrika knjiga, 2017.

Offen, Karen. "Defining Feminism: A Comaparative Historical Approach". Signs vol. 14, no. 1 (Jesen 1988): 119-157. http://www. jstor.org/stable/3174664.

Offen, Karen. European Feminisms 1700-1950. A Political History. Stanford: Stanford University Press, 2000.

Opitz-Belakhal, Claudia. Geschlechtergeschichte. Frankfurt-New York: Campus Verlag, 2010.

Parenta, Miloš. "Ženin društveni položaj”. Glasnik Srpske pravoslavne patrijaršije br. 18 (1927).

Petrović, Mileva. “Opštinski izbori i naše žene”. Ženski pokret br. 2 (1920).

Planert, Ute. "Vater Staat und Mutter Germania: Zur Politisierung des weiblichen Geschlechts im 19. und 20. Jahrhundert". U Nation, Politik und Geschlecht. Frauenbewegungen und Nationalismus in der Moderne. Ur. Ute Planert. Frankfurt-New York: Campus Verlag, 2000, 15-65.

Stefanović, Svetlana. "Nation und Geschlecht. Frauen in Serbien von der Mitte des 19. Jahrhunderts bis zum Zweiten Weltkrieg". 
PhD diss., Univerzitet u Lajpcigu, 2013. http://nbn-resolving.de/ urn:nbn:de:bsz:15-qucosa-203559.

Stefanović, Svetlana. “Žene u službi nacije i vojske”. Knjiženstvo no. 6 (2016). http://www.knjizenstvo.rs/magazine.php?text=197.

Stolić, Ana. Sestre Srpkinje. Pojava pokreta za emancipaciju žena i feminizma u Kraljevini Srbiji. Beograd: Evoluta, 2015.

Sundhaussen, Holm. "Nationsbildung und Nationalismus im DonauBalkan-Raum”. Forschungen zur osteuropäische Geschichte no. 48 (1993): 233-258.

Šljukić, Srđan. "Entoni Smit o odnosu nacionalnog identiteta i mita o izabranosti”. Zbornik Matice srpske za društvene nauke no. 139 (Februar 2012), 283-293. http://www.maticasrpska.org.rs/stariSajt/casopisi/drustvene_nauke_139.pdf.

Yuval-Davis, Nira. Rod i nacija. Prevela Mirjana Paić Jurinić. Zagreb: Ženska infoteka, 2004.

Walby, Sylvia. Theorizing Patriarchy. Cambridge: Basil Blackwell, 1990.

Wallach-Scott, Joan. Rod i politika povijesti. Prevela Marina Leustek. Zagreb: Ženska infoteka, 2003.

Zaharijević, Adriana. "Kratka istorija sporova: Šta je feminizam". U Neko je rekao feminizam. Kako je feminizam uticao na žene 21. veka. Ur. Adrijana Zaharijević. Beograd: Heinrich Böll Stiftung, 2012, 384-415.

Zaharijević, Adriana. "Dodatak 7: Feminističke teorije, pozicije i teorijski okviri”. U Neko je rekao feminizam. Kako je feminizam uticao na žene 21. veka. Ur. Adrijana Zaharijević. Beograd: Heinrich Böll Stiftung, 2012, 416-424.

Zundhausen, Holm: Istorija Srbije od 19. do 21. veka. Preveo Tomislav Bekić. Beograd: Clio, 2009.

\section{GENDER AND NATION: KEY ARGUMENTS}

Is feminism an ideology, a personal belief, a network of theoretical positions, a starting point in examining the phenomena which do not necessarily concern solely women anymore, a conceptual framework, a set of various activities whose goal is to improve the position of women, an attempt to read histo- 
ry in a different manner; or is it all of those things? Is there a single definition of feminism? What is gender? What is the difference between women's and gender studies? Is nation an eternal and universal, or a specifically modern notion? Do women have nationality/homeland? Why are the idea of nation, the construction of national identity, and the processes of the formation/education of a nation infused with gender-specific connotations? What has national engagement brought to women? The aim of this text is to clarify the aforementioned terms and notions from the perspective of feminist theory.

Keywords: feminism, sex/gender, nation, feminist movement, feminist theory 